\title{
IIIISGUCDERGI.ORG
}

"IȘ, GÜç" ENDÜSTRI ILIȘKILERI VE INSAN KAYNAKLARI DERGISi

"IS, GUC" INDUSTRIAL RELATIONS AND HUMAN RESOURCES JOURNAL

\section{New actors within the European Employment strategy (EES): the presence of the legislative power and trade unions in a coexistent dialogue in Luxembourg (2005-2008)}

\author{
Patrick Thill \\ CEPS/INSTEAD \\ Patrick.Thill@ceps.lu
}

Ekim/October 2009, Cilt/Vol: 11, Say1/Num: 5, Page: 51-65 ISSN: 1303-2860, DOI: 10.4026/1303-2860.2009.0125.x

Makalenin on-line kopyasına erişmek için:

http://www.isgucdergi.org/?p=makale\&id=397\&cilt=11\&sayi=5\&yil=2009

To reach the on-line copy of article:

http://www.isguc.org/?p=article\&id=397\&vol=11\&num=5\&year=2009

Makale İçin İletişim/Correspondence to:

Yazarların e-posta adresleri verilmiştir. Writers e-mail was given for contact. 
(C) 2000- 2009

"İşGüç̧" Endüstri İlişkileri ve İnsan Kaynakları Dergisi

"İşGǚç" Industrial Relations and Human Resources Journal

Ekim/October 2009, Cilt/Vol: 11, Say1/Num: 5

ISSN: 1303-2860, DOI: 10.4026/1303-2860.2009.0125.x

Editör/Editor-in-Chief

Aşkın Keser (Kocaeli University)

Editör Yardımcıları/Co-Editors

K.Ahmet Sevimli (Uludă̆ University)

Gözde Yilmaz (Kocaeli University)

Uygulama/Design

Yusuf Budak (Kocaeli Universtiy)

\author{
Yayın Kurulu / Publishing Committee \\ Dr.Zerrin Firat (Uludăg University) \\ Doç.Dr.Aşkın Keser (Kocaeli University) \\ Prof.Dr.Ahmet Selamoğlu (Kocaeli University) \\ Yrd.Doç.Dr.Ahmet Sevimli (Uludağ University) \\ Yrd.Doç.Dr.Abdulkadir Şenkal (Kocaeli University) \\ Yrd.Doç.Dr.Gözde Yilmaz (Kocaeli University) \\ Dr.Memet Zencirkıran (Uludağ University)
}

Uluslararası Danışma Kurulu / International Advisory Board

Prof.Dr.Ronald Burke (York University-Kanada)

Assoc.Prof.Dr.Glenn Dawes (James Cook University-Avustralya)

Prof.Dr.Jan Dul (Erasmus University-Hollanda)

Prof.Dr.Alev Efendioğlu (University of San Francisco-ABD)

Prof.Dr.Adrian Furnham (University College London-İngiltere)

Prof.Dr.Alan Geare (University of Otago- Yeni Zellanda)

Prof.Dr. Ricky Griffin (TAMU-Texas AEM University-ABD)

Assoc. Prof. Dr. Diana Lipinskiene (Kaunos University-Litvanya)

Prof.Dr.George Manning (Northern Kentucky University-ABD)

Prof. Dr. William (L.) Murray (University of San Francisco-ABD)

Prof.Dr.Mustafa Özbilgin (University of East Anglia-UK)

Assoc. Prof. Owen Stanley (James Cook University-Avustralya)

Prof.Dr.Işık Urla Zeytinoğlu (McMaster University-Kanada)

Danışma Kurulu / National Advisory Board

Prof.Dr.Yusuf Alper (Uludağ University)

Prof.Dr.Veysel Bozkurt (Uludağ University)

Prof.Dr.Toker Dereli (Işık University)

Prof.Dr.Nihat Erdoğmuş (Kocaeli University)

Prof.Dr.Ahmet Makal (Ankara University)

Prof.Dr.Ahmet Selamoğlu (Kocaeli University)

Prof.Dr.Nadir Suğur (Anadolu University)

Prof.Dr.Nursel Telman (Maltepe University)

Prof.Dr.Cavide Uyargil (İstanbul University)

Prof.Dr.Engin Yildırım (Sakarya University)

Doç.Dr.Arzu Wasti (Sabancı University)

Dergide yayınlanan yazılardaki görüşler ve bu konudaki sorumluluk yazarlarma aittir.

Yayınlanan eserlerde yer alan tüm içerik kaynak gösterilmeden kullanılamaz.

All the opinions written in articles are under responsibilities of the outhors.

None of the contents published can't be used without being cited. 


\title{
New actors within the European Employment strategy (EES): the presence of the legislative power and trade unions in a coexistent dialogue in Luxembourg (2005-2008)
}

\author{
Patrick Thill \\ CEPS/INSTEAD \\ Patrick.Thill@ceps.lu
}

\begin{abstract}
:
The appropriation of the Lisbon agenda 2010 by the legislative power and its participation in the elaboration of the National Reform Programmes (NRP) of 2005 and 2008 go hand in hand with an increasing parliamentary involvement in EU dossiers. In the context of the Lisbon treaty, this involvement will potentially increase. As regards the debates that have surrounded the Lisbon Strategy, it is shown that Luxembourg's House of Representatives brought together both representatives from the government and the legislative power with the civil society to generate a debate on the future reforms to be put forward. Considering the panoply of actors involved, it is further argued that the resulting dialogue does coexist with more traditional and institutionalized instruments of dialogue that have embodied the consensus-seeking "Luxembourg social model".
\end{abstract}

Keywords: European Employment Strategy (SEE), social dialogue, National Reform Programmes (NRP), legislative power, civil society, industrial relations 


\section{Introduction}

In 2005, the re-launch of the Lisbon strategy centered on the objectives of employment and growth. In the long run, it further aimed at the implementation of a knowledge society. An ambitious reform process (Agenda 2010 or Lisbon I) was put forward, seeking to revitalize the competitiveness of the European economies and produce a "virtuous linkage between social cohesion and growth" (Fontagné, 2005). ${ }^{1}$ However, since the Lisbon I process has been initiated in 2000 , the process has also been marked by an intention of the European leaders to integrate more closely Europe's social partners, its national parliaments, and a broad range of civil society representatives within a regular procedure of national consultation. In order to achieve this objective, the different forms of intranational dialogue within the EU member states were activated. In spite of the fact that a survey carried out in 2003 by the European Parliament underlined major differences in the appropriation process throughout the EU member states ${ }^{2}$, it is argued that the appropriation of the 2010 Agenda went through a consultative process in Luxembourg.

Two underlying developments are analyzed in this contribution: on the one hand, a process of "Europeanization" has impacted upon the House of Representatives as the role of national parliaments has generally been promoted by the EU treaties (Table 3). The parliament also complied with the subsidiarity principle, ensuring that decisions are taken as closely as possible to the citizen. On the other hand, the government has shown its willingness to let the rules of Luxembourg's well-established social dialogue play through a deeper implication of social partners and representatives from the civil society in what we identify as a coexistent dialogue. This contribution is also based on a larger study of new actors within the SEE (Thill, 2009) while it adds up to recent studies carried out on the "Luxembourg social model" (Hirsch, 2003; Zahlen, 2003; Clément, 2006; Thill, Thomas, 2009).

\section{Mode of governance}

The mode of governance of the revised 2010 Agenda was deeply rooted in the European Employment Strategy (EES), with key developments including the Extraordinary European Council Meeting on Employment (1997) in Luxembourg, the Amsterdam Treaty (1997) that legally formalized the SEE through the integration of a new title on employment (Title VIII) into existing community law, and the Lisbon Council (2000) providing a definition of the objectives of the

\section{Table 1}

The mode of governance of the EES since the Amsterdam Treaty (1997-2005)

Mode of governance of the EES (1997-2005)

- Integrated guidelines (LDI): common priorities for EU member states in terms of employment policies

- National Action plans (PAN): implementation of the common priorities on a national level (oneyear cycle)

- Recommendations: adoption of specific recommendation by the European Council

Mode of governance of the EES, simplified by the re-launch of the Lisbon strategy (2005)

- Integrated guidelines for growth and jobs (LDI)

- National Reform Programmes (NRP), based on a three-year cycle

- Annual report on growth and jobs by the European Commission: analysis of the NRP of all the EU member states

- Recommendations adopted by the European Council

- Increased implication of social partners, national parliaments and the civil society

1 Translated from French by the author.

2 In the context of an interparliamentary meeting between the European parliament and national parliaments on the Lisbon strategy in 2006, national parliaments responded to a questionnaire that highlighted how they organized the Lisbon agenda (see European parliament contribution "Les parlements en route vers Lisbonne"). 
Lisbon strategy as well as an intra-governmental method of benchmarks and mutual learning processes (Open Method of coordination, MOC).

The evolution from Lisbon I (2000) to Lisbon II (2005) was marked by the awareness that the majority of the initially defined Lisbon objectives could not been entirely achieved (Kok, 2004). Beyond this, public opinion polls suggested that European citizens were disappointed (less though in Luxembourg) by the evolutions on the employment market and their non-participation in community affairs. EU decision-makers became increasingly aware that a shift towards an appropriation of the strategy by the national parliaments and the civil society was an indispensable step to guarantee the success of the strategy. What was considered theoretically in the major post-Lisbon I texts was well summarized by Luxembourg's Prime Minister, Jean-Claude Juncker, declaring during Luxembourg's Presidency of the European Council in 2005, that the National Reform Programmes, the NRPs, "will be established after a consultation with social partners in the member states and after the consultation with all the regional and local authorities (...) and are submitted to the national parliaments that could, if they wish, discuss them" (Juncker, 2005).

The mode of governance of the Lisbon strategy also underlined that the "Integrated guidelines for Growth and Jobs" (LDI, see Table 2) constituted the basis for the so-called NRPs (Table 4), the successors of the oneyear cycle National Actions Plans (NAP) which each member state had to elaborate and send to the European Commission. In Luxembourg, the Tripartite coordination committee invited the Competitiveness $\mathrm{Ob}$ servatory of the Ministry of the Economy and Foreign Trade to coordinate the first 2005 NRP with the help of the "Lisbon network", established in 2005. The European Commission then issues recommendations after a thorough evaluation of the documents. Annual implementation reports complement the mode of governance. Whereas NAP's were voted as normal bills by the House of Representatives, the new NRP's are approved, but not considered as legal texts by the Parliament. The NRP's, elaborated for a three-year cycle highlight the national priorities, whereas they put forward objectives to achieve the Lisbon goals. Two consecutive annual implementation reports should detail policy responses and trace back the results of the objective presented in the NRP. In Luxembourg, the Presidency of the European Council (2005) $)^{3}$ was followed by important tripartite agreements in 2006 between the Government and the social partners within the framework of the Tripartite coordination committee (Clément, 2008). ${ }^{4}$

In Luxembourg, the legislative power $^{5}$ (House of Representatives) is a democratically elected body representing the various political ideologies; it joined the institutional landscape of industrial relations by engaging the civil society in a parliamentary dialogue and this by means of already existing instruments. Since 2005, the House of Representatives has faced the challenges as a new actor within the circle of the Lisbon strategy. More recently, within the framework of Luxembourg's national legislative elections of June 2009, a couple of political parties want the legislative power to be deeper involved in the negotiations of the Tripartite coordination committee.

On the academic level, the economist Mariusz-Jan Radlo concluded in his 2006 study of

3 Eurobarometer Special Surveys, October and November 2004/2005.

4 The "Tripartite coordination committee", the embodiment of what is often referred to as the "Luxembourg social model", is based on a 1977 law destined to keep unemployment low and competitiveness high as a response to steel crisis in the 70's. It gathers governmental, employee and union representatives in a consensus-seeking dialogue process.

5 Luxembourg's Constitution does not refer to a parliament (in French: Parlament), but to the "Chambre des Députés". Throughout this contribution, we opted for the term "House of Representatives" to designate the legislative power in Luxembourg. 
Table 2

Integrated guidelines for Growth and Jobs 2005-2008/2008-2011)

\section{Macroeconomic guidelines (GOPE prior to 2005)}

(1) To secure economic stability

(2) To safeguard economic and fiscal sustainability

(3) To promote a growth- and employment- orientated and efficient allocation of resources

(4) To secure economic stability for sustainable growth

(5) To ensure that wage developments contribute to macroeconomic stability and growth

(6) To contribute to a dynamic and well-functioning EMU

\section{Microeconomic guidelines (GOPE prior to 2005)}

(7) To increase and improve investment in $R \& D$, in particular by private business

(8) To facilitate all forms of innovation

(9) To facilitate the spread and effective use of ICT and build a fully inclusive information society

(10) To strengthen the competitive advantages of its industrial base

(11) To encourage the sustainable use of resources and strengthen the synergies between environmental protection and growth

(12) To extend and deepen the internal market

(13) To ensure open and competitive markets inside and outside Europe and to reap the benefits of globalization

(14) To create a more competitive business environment and encourage private initiative through better regulation

(15) To promote a more entrepreneurial culture and create a supportive environment for SMEs

(16) To expand, improve and link up European infrastructure and complete priority cross-border projects.

\section{Employment guidelines (LDE prior to 2005)}

(17) Implement employment policies aiming at achieving full employment, improving quality and productivity at work, and strengthening social and territorial cohesion

(18) Promoting a life-cycle approach to work.

(19) Ensuring inclusive labor markets, enhance work attractiveness, and make work pay for job-seekers, including disadvantaged people, and the inactive.

(20) Improve matching of labor market needs

(21) Promote flexibility combined with employment security and reduce segment market segmentation, having due regard to the role of the social partners.

(22) Ensure employment-friendly labor cost developments and wage-setting mechanisms

(23) Expand and improve investment in human capital

(24) Adapt education and training systems in response to new competence requirements

\section{Source: European Commission}

the elaboration of NRPs that "in the majority of the cases, the role of the Parliaments (...) was well limited" and that "the tendency was to treat the NRPs like any other Community document" (Radlo, 2006). As regards the a posteriori parliamentary control of the national NRPs, the economist Ian Begg opined that "the national parliaments did not really have the means of supervising the go- vernmental performance" (Begg, 2006). Others qualified the NRPs as being mere "bureaucratic activity reports" (European Economic and Social Committee, 2005) whereas the failure of the Lisbon strategy in its entirety has often been underlined (Collignon, 2008). However, Bongardt and Torres (2007) put forward the idea that "stakeholder involvement in NRPs should augment 
national ownership of reforms" with the objective "to help overcome national resistance to reforms with an EU rationale". More recently, the hypothesis that the European Union would generally reduce the power of national parliaments has been put forward (Duina and Oliver, 2005).

Beyond these critical views of the Lisbon process, we can observe that the implication of parliaments within the Lisbon strategy and, at a technical level, in the elaboration of the NRPs, has never been carefully examined. As Table 2 shows, the implication of na- tional parliaments is a recent development in the European integration process, rooted in the Amsterdam Treaty. The Lisbon Treaty (2007) would provide, if it were to come into effect, additional means to the national parliaments as regards their interference into the creational process of community draft bills.

\section{Luxembourg's House of Representati- ves and the European Union}

Over the last years, Luxembourg's House of Representatives has turned its attention

Table 3

National parlements in the EU Treaties (1985-2007)

\begin{tabular}{|c|c|}
\hline Treaty & Reference to the national parliaments \\
\hline Single Act (1986) & - No reference \\
\hline Maastricht Treaty (1992) & $\begin{array}{l}\text { - A declaration, the "Declaration on the role of national parliaments in } \\
\text { the European Union", was added to the Titles and Protocols of the } \\
\text { Treaty } \\
\text { - Reinforcement of contacts and meetings between national parliaments } \\
\text { and the European Parliament } \\
\text { - Transmission to national parliaments (via their governments) of draft } \\
\text { bills }\end{array}$ \\
\hline Amsterdam Treaty (1997) & $\begin{array}{l}\text { - In addition to the newly added Title VIII on employment was } \\
\text { incorporated a "Protocol on the role of national parliaments in the Eu- } \\
\text { ropean union", formalizing and detailing the missions of the COSAC } \\
\text { - The "Protocol" stipulates that national parliaments have a 6-week delay } \\
\text { to examine a draft bill before it will be put on the agenda of the } \\
\text { Council. }\end{array}$ \\
\hline Nice Treaty (2001) & - "Protocol" of 1997 on the role of national parliaments \\
\hline $\begin{array}{l}\text { The Treaty Project establishing a } \\
\text { Constitution for Europe (2004) }\end{array}$ & $\begin{array}{l}\text { - The "Protocol on the role of national parliaments" becomes the first } \\
\text { "Protocol of the Treaty Titles" }\end{array}$ \\
\hline Lisbon Treaty (2007) & $\begin{array}{l}\text { - Identical text, but including under Title I (Art.1-8) that information } \\
\text { based on national parliaments, among which figure the compulsory } \\
\text { transmission of legislative texts between the community institutions and } \\
\text { the national parliaments (Art.2) and the obligation for these to proceed } \\
\text { to assessments that are addressed to the European Parliament, the } \\
\text { Council and the European Commission, deciding on the conformity of } \\
\text { a legislative text to the principle of subsidiarity (art.3). } \\
\text { - When the Lisbon Treaty enters into force, a special procedure introdu- } \\
\text { ces the following procedure: in accordance to the principle of subsidia- } \\
\text { rity, the European Commission can take back a legislative text if a third } \\
\text { of the national parliaments believe that the project does not comply with } \\
\text { the principle. However, the European Commission returns the project to } \\
\text { the Council and the European Parliament in order to decide to continue } \\
\text { the procedure; in the case a project is maintained and a majority of } \\
\text { national parliaments still pronounces certain objections. }\end{array}$ \\
\hline
\end{tabular}

Source: European Commission 
more systematically and professionally to the activities of the European institutions. Similarly, a considerable amount of EU directives had to be transposed into national law. In addition to so-called "modes of soft-governance" (Borrás and Conzelmann, 2007), it has set up its own European strategy in 2006 with the mission "to inform the representatives at the earliest time and of the most effective manner (...) on the European legislation projects" and to seek "the dialogue through public hearings at the Parliament".

The role of Luxembourg's House of Representatives within the Lisbon process can't be dissociated of other involvements in EU affairs. They implied a considerable process of adjustment reinforced by the "Protocol on the role of the national parliaments in the European Union" annexed to the Amsterdam Treaty. As a matter of fact, two observations are worth mentioning: first, parliamentary involvement aims to increase the visibility of the legislative power in the public sphere, often extending the strategy's objectives to the local or public level. Second, an implication of the legislative power at EU level could reinforce the "public character of the parliamentary responsibility" (Tsakatika, 2007). A couple of examples emphasize the recent increase of parliamentary activities at EU level:

- A key instrument of the cooperation between national parliaments and the European Parliament is the COSAC (Conference of the Bodies specialized in the Community and European businesses of the Parliaments of the European Union $)^{7}$, created in Madrid in 1989. This inter-parliamentary body was formally recognized by the "Protocol" annexed to the Amsterdam Treaty. The Conference is authorized to submit to the European institutions every kind of contribution it considers necessary. Alternatively, it has to be regularly informed about the status of draft directives. Each Member state is allowed to send six national parliamentary representatives to the biannual meetings of the COSAC. One of the basic principles is emphasized in what is referred to as the Conference's "Code of conduct" for national parliaments, established in Copenhagen and adopted in 2002. The Code points out that "the national parliament receives relevant information on the initiatives of the Community, as well of the government as of the institutions of the Community, and this sufficiently in time so that it can study them before the decisions are made".

- Once a year, a delegation of the House of Representatives takes part in a parliamentary meeting on the Lisbon strategy organized by the European Parliament in Brussels. The first parliamentary meeting chaired by the President of the European Parliament, took place, in close cooperation with the Luxembourg Presidency of the Council, in March 2005, shortly before the European Spring Council. During the meeting, more than 200 participants from 25 Member states concluded to strengthen the inter-parliamentary co-operation and dialogue, identifying potential future priorities of the EU.

- In 2005, the European Parliament set up the "Group of the 33" (or G33) which comprises 33 European representatives and a secretariat. As another example of a soft governance instrument, the G33 has as a main mission to supervise the evolution of the strategy and formulate a contribution to the Spring Council (Borrás, 2009).

- In Luxembourg, the administration has not been exempt from organizational adaptations: the different parliamentary committees, in charge of both the examination of draft bills and the organization of debates or public hearings, ensure within the framework of Luxembourg's general legislative procedure, the transposition of directives. The daily agenda of the different committees has been supplemented 
by regular examinations of EU communications or proposals. In order to face professionally the new challenges of a more accentuated implication at the European level, a large array of information resources have been made available to the representatives and the administration. Among the tools figure the IPEX ${ }^{8}$ database allowing an electronic exchange of documents as well as the databases PreLex and EURLex ${ }^{9}$.

- Finally, the House of Representatives has been represented in the European Parliament by a permanent representative.

\section{The House of Representatives and its implication in the elaboration of the 2005- 2008 and 2008-2010 NRPs}

As above-mentioned, NRPs based on "Integrated guidelines for Growth and jobs" have been at the core of the more simplified EES. As regards the elaboration of first NRP 2005-2008 cycle in Luxembourg, the parliamentary procedure implied a strong dialogue between the representatives of civil society, the House of Representatives and the official governmental departments involved in the elaboration of Luxembourg's NRP.

\section{Table 4}

The European Employment strategy: Mode of governance

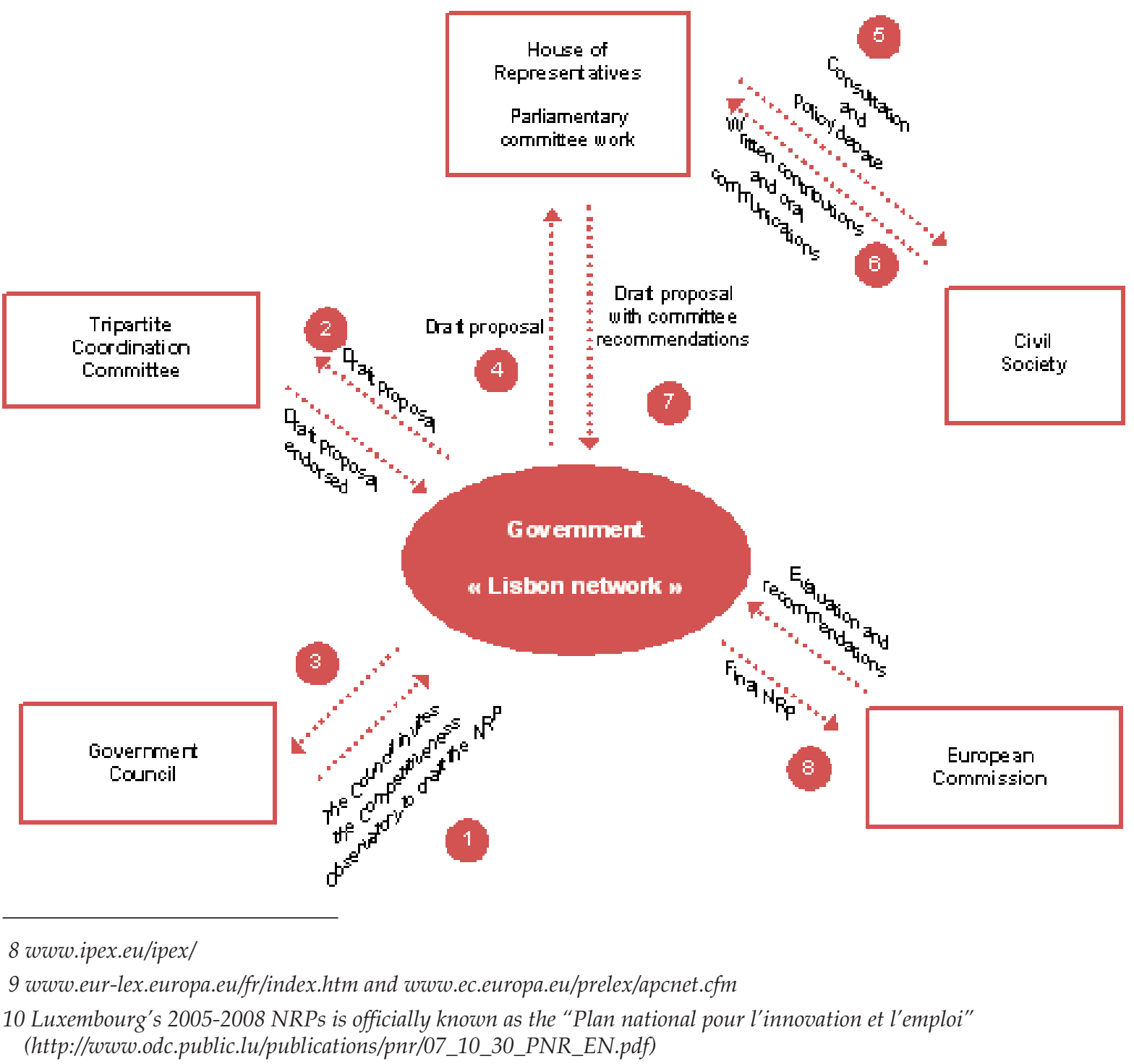


Technically speaking, three stages of the parliamentary implication in the elaboration process of the NRP can be made out:

\subsection{First preparatory stage}

Since 2005, Luxembourg's House of Representatives has been implicated in the Lisbon agenda via its "Economic and Energy Committee ${ }^{\prime \prime 11}$ whose mission it is to coordinate and supervise Lisbon-related parliamentary works. As for the governmental counterpart, the Ministry of the Economy and Foreign trade $^{12}$, represented by the Competitiveness Observatory ${ }^{13}$, assumed the governmental coordination and supervision of the Lisbon strategy.

In February 2005, the Minister of the Economy and Foreign trade met with the representatives of the eleven parliamentary committees of the House of Representatives in order to present both the broad outlines of the Lisbon agenda and the administrative constraints. It was decided that the "Economic and Energy Committee" should proceed to the distribution of the "Integrated guidelines for growth and jobs" among the parliamentary committees.

After several parliamentary meetings in 2005, the "Economic and Energy Committee" defined both the procedure and the method to be adopted. It agreed upon a parliamentary agenda while making sure that this one accorded with the governmental agenda (i.e. 2005 Council Presidency, Tripartite coordination negotiations). It further launched a first intra-committee debate during these meetings which crystallized the various positions of the committee representatives about the LDI. From July to November 2005, the "Economic and Energy Committee" met six times to discuss the organization of the Lisbon agenda. Similar to the Competitiveness Observatory, the coordinating parliamentary committee met on July 19, 2005 with representatives from the European Commission's Directorate-General for
Employment, Social Affairs and Equal opportunities to receive technical details about the drafting of Luxembourg's 2005-2009 NRP.

\subsection{Second preparatory stage}

During a second phase, the LDI were distributed among the parliamentary committees, based on an internal document that had been drawn up by the administration. In spite of the fact that some LDIs fit into the missions of several committees, it was especially paid attention to the compatibility of the LDI with the specialization of each parliamentary committee. As an example, the "Employment and Work committee" devoted the essential part of its reflections to LDI 17 to 24 (related to these were LDI $2,4,5$ ) as the committee deals in particular with employment issues. The Committee therefore emphasized the importance of the law of June 30, 2004 on collective labor agreements ${ }^{14}$ (Clement, 2008). As far as the "Economic and Energy Committee" was concerned, it discussed the LDI focusing on the European industrial base, the strengthening of the interior market, the national and international competitiveness of markets (LDI 10 to 13$)$.

\subsection{Third preparatory stage}

After the distribution of the LDI among the committees, it was decided to put the study of the LDI onto their agenda. The "Economic and Energy Committee" proceeded to the collection of the various standpoints, recommendations and priorities in order to include them in a coordinated document destined to the Competitiveness Observatory, after being analyzed and approved by the coordinating committee on September 27, 2005.

\subsection{The procedure for the 2008-2010 NRP}

In December 2007, the European Commission reached consensus among the EU Member states on the LDI of the new 2008-2010 triennial cycle. For this cycle, it was a question of

11 «Commission de l'Economie, de l'Energie, des Postes et des Sports »

12 www.eco.public.lu/

13 wwww.odc.lu

14 http://www.gouvernement.lu/dossiers/social_emploi/relcoll/index.html 
not modifying the LDI in application for the PNR 2005-2008, but rather of being focused more on their implementation. ${ }^{15}$ The European Council of March 2008 confirmed that the cycle 2008-2010 should be centered on their implementation. ${ }^{16}$ The Council of March was preceded again (March 8, 2008) by a European Tripartite Social Summit discussing the next stages of the strategy. As regards Luxembourg's House of Representatives, the modus operandi for the coming years remained unchanged. A second implication of the parliamentary committees highlighting their priorities took place. However, the 2008 exercise was facilitated by the fact that the elaboration process of the NRP was not changed due to the fact that the same LDI were considered. Again commissioned to the "Economic and Energy Committee", the NRP coordination procedure remained mostly unchanged.

As part of the parliamentary consultation process, Luxembourg's House of Representatives organized two public hearings (March 5, 2008 and April 10, 2008) on the Lisbon agenda and on a draft version of the NRP. A meeting of the "Economic and Energy Committee" with the coordinating ministry took place on June 20 , 2008. It was during the meeting of the Government Council ${ }^{17}$ of October 17, 2008 that the 2008-2010 NRP cycle was approved after being discussed during the consultation debate (see 4.1.).

\section{The debates with the civil society (2005- 2008): towards a coexistent dialogue in Lu- xembourg?}

\subsection{The consultation debate (" débat de con- sultation »)}

After the transmission of the contributions to the Competitiveness Observatory, the procedure envisaged a second intervention by the
House of Representatives within the framework of a public policy debate on the Lisbon agenda. The debate was launched on the basis of a first draft of the NRP, submitted in advance to the representatives. Figuring on the agenda together with other legislative texts, the study and public debate took place on November 16, 2005 during a plenary session. It was then followed by the vote of two parliamentary motions ("motions parlementaires"). According to article 85 of its internal regulations $^{18}$, a parliamentary motion can be filed if at least five members of parliament take the initiative. The debate, just like the faculty to formulate parliamentary motions, figures among the administrative control tools available to the legislative power in order to orientate the government in its activities and missions.

Important for the argument in this contribution are the following elements of the debate: ${ }^{19}$

- The debate opens with a brief presentation of the political, social and economic context. The following general NRP-related subjects are discussed: the implementation of a European knowledge society, the importance of research and innovation as a tool to boost competitiveness, the creation and development of companies, the future spatial development of the country, better regulation and the importance of child-care facilities to increase the employment rate of women on the labor market (pp. 62-64).

- The debate is built around two axes: on the one hand, the three opposition parties in the parliament (the Green Party, the Democratic Party and the ADR Party ${ }^{20}$ ) critically assess the first NRP draft. In spite of the fact that the main criticisms do not counter the legitimacy of the document, some critical inputs go in tandem with arguments reflected in the academic literature, i.e. the

\footnotetext{
15 http://ec.europa.eu/growthandjobs/pdf/european-dimension-200712-annual-progress-report/200712-annual-report_en.pdf 16 www.consilium.europa.eu/ueDocs/cms_Data/docs/pressData/fr/ec/99435.pdf

17 "Conseil de Gouvernement": Governmental institution regularly reuniting the ministers of the Government approving policies before being introduced into parliament.

18 www.chd.lu

19 The verbatim of the debate under question is available on www.chd.lu

20 www.greng.lu/cms/home.php, www.dp.lu, www.adr.lu
} 
vagueness of the document, the absence of a qualitative dialogue with the civil society, the preeminence in the preliminary discussions with the role of social partners to the general detriment of the House of Representatives.

- Those in favor of the document emphasize the fact that the House of Representatives was consulted, contrary to other plans or programmes that had been addressed in the past by the government to the European Commission. Similar to the government, the House of Representatives dealt with certain constraints. Both the panoply and complexity of the objectives put forward in the 2005-2008 NRP could not have been exposed in their entirety in a document that should, as initially envisaged by the European Commission, not exceed more than forty pages.

- Two parliamentary motions were finally submitted to the vote. The first motion, deposited by the two coalition parties CSVLSAP $^{21}$ were approved and invited the government "to keep the House of Representatives informed at regular intervals on the progress made in the implementation process of the NRP and of the evaluation carried out by the European Commission and reserves itself a right to organize (...) a debate on the application of the programme" 22 The second, rejected and presented by the opposition parties, obliges the government "to present details on the objectives and the integrated guidelines" and "to consult the House of Representatives before, during and after the meetings of tripartite".

The debate resulting from the work that had been done at committee level highlights the willingness to be implicated in the Lisbon agenda. It can also be observed that the priorities of the parliament did not differ much from what the government had already drafted. As a matter of fact, the debate contributed to detect the different positions of the political parties within the parliament.

\subsection{The public hearings}

The policy debate ("débat d'orientation") of November 16, 2005 was followed by three public hearings (October 24, 2006, March 5, 2008 and April 10, 2008) dealing with the Lisbon agenda. These public hearings were organized by the "Economic and Energy Committee", in cooperation with the Competitiveness Observatory. If the 2006 debate gathered both experts from the Lisbon network and members of the parliament, the public hearings were much more related to the follow-up of the NRPs and the two implementation reports (2006 and 2007). More generally, the public hearings positioned the debate about the Lisbon agenda on a larger scale; they achieved to gather representatives of the civil society, members of the coordinating parliamentary committee, as well as both the ministers of the economy and foreign trade and work and employment. The audience included ministerial representatives and experts from the sectors of research, economy, vocational training, and the environment. Representatives from all the NRP covered issues took part and were faced with the inputs of both oral and written communications to the debate.

The first public hearing took place on October 24,2006 . The government presented a draft implementation report to the participants. As far as the other two public hearings are concerned, new elements could be made out: besides a representative from Luxembourg's trade unions, three international experts, Lionel Fontagné (author of a widely read competitiveness report on Luxembourg, see bibliography), Katarina Lindahl of the European Commission's Directorate-General for Employment, Social Affairs and Equal opportunities of the European Commission and the expert, Joachim Spangenberg, presented technical reports about the Lisbon strategy during the debate of March 5, 2008. 
As far as the unions are concerned, the representative of the European Secretariat of the CGT and the LCGB, Nico Clement, was for instance in favor of a reorganization of the Lisbon strategy in order to create a more social Europe; it would therefore be imperative to restore the confidence of the European citizens. ${ }^{23}$

Beyond the representatives of the different ministries and members of the coordinating parliamentary committee, the second public hearing (April 10, 2009) gathered more than 20 representatives of the civil society, among which were a representative of Luxembourg's Company Union (UEL), the OGB-L, Luxembourg's circle of NGOs, the National Council of Women Luxembourg (CNFL), and representatives from environmental associations (i.e. the "Haus vun der Natur" organization or Greenpeace).

\subsection{The consultation debate for the 2008- 2010 NRP}

Within the framework of the 2008-2010 NRP, a bilateral meeting between the governmental Lisbon coordinators, a delegation of the European Commission, the "Economy and Energy Committee", and the social partners took place on June 20, 2008 at the Ministry of the Economy and Foreign trade. After the two public hearings in the House of Representatives, Luxembourg's Economic and Social Council ${ }^{24}$ assessed the LDIs, reiterating that their analysis "falls under an approach of coordination and coherence of the whole of the continued policies" (p. 3). If the development of the first 2005-2008 NRP was discussed within the framework of an orientation debate, the new 2008-2010 NRP was the subject, on October 16, 2008, of another consultation debate during a plenary session in the House of Representatives. The final version of the NRP was sent to the European Commission in October 2008.

\section{Conclusions}

The research on the role of national parliaments within the EES allows the following conclusions:

Within the framework of the EES and its implementation at the national level in Luxembourg, the House of Representatives adopted an active role: we identified the existence of a multi-faceted political debate; the resulting dialogue did not only take place at several levels within the structures of Luxembourg's parliament, but it also enabled to gather governmental and legislative representatives, as well as a broad range of members of the civil society to engage in a mutual consultation dialogue on Europe's reform process.

Moreover, it can be observed that the abovementioned dialogue strongly coexisted with other traditional and consensus-seeking forms of dialogue in Luxembourg. In addition to the usual bilateral governmental meetings with social partners, we mentioned the tripartite meetings in the context of the "Luxembourg social model" where social partners are involved in the discussions of vital issues leading to a widely accepted consensus before policy is drafted. More recently, it has often been suggested that the parliament should play a more vital role in the tripartite negotiations. In the new 2009 post-election governmental agreement, this idea has been emphasized again.

We further showed that the parliament employed already existing available means to adapt itself to the challenges of the Lisbon strategy, while it had already accumulated a considerable experience in the transposition of EU directives. An increasing implication at EU level in the course of the last years can be accentuated when the Lisbon Treaty enters into force. The analysis on the role of national parliaments seems to confirm that the "national reform strategies largely pursue al-

\footnotetext{
23 European Secretariat of the CGT and the LCGB, www.secec.lu; Luxembourg Christian Union, www.lcgb.lu/fr: Luxembourg's Company Union, www.uel.lu; Luxembourg's Independent Union, wwww.ogbl.lu; Luxembourg's circle of NGOs, www.ongd.lu; National Council of Women Luxembourg, www.cnfl.lu; Haus vun der Natur, www.haus-natur.lu; Greenpeace, www.greenpeace.lu 
ready existing national objectives and are therefore debated vividly in their own respective public spheres" (Borrás, 2009: 108).

Finally, we can identify a triple role of the House of Representatives in the implementation of the Lisbon agenda: an indirect, but active role through the development of priorities at committee level; a supporting role as the result of putting forward parliamentary motions inviting the government to carry out the reform process to boost competitiveness; and, more particularly, an advisory role to the intergovernmental Lisbon network through the organization of public meetings with the civil society and experts.

It remains to be seen if and how Luxembourg's parliament will move beyond its traditional legislative responsibilities conferred to it by Constitution, and how it will position itself within the national circle of already existing actors of industrial relations.

\section{Bibliography}

Begg, I. 2006, "Economic reform governance in the EU and its limits", in Radlo, J.M. et Bates, C. (Ed.) National Reform programs: Key successful future of the European Project, Gdansk Institute for Market Economics, Varsovie.

Bongardt, A. and Torres, F, 2007, "Institutions, Governance and Economic Growth in the EU: is there a role for the Lisbon strategy", Intereconomics.

Borrás, S. 2009, "The Politics of the Lisbon Strategy: The changing role of the Commission", West European Politics, 32, 1.

Borrás, S. and Conzelmann, T. 2007 "Democracy, Legitimacy and Soft modes of governance in the EU: The empirical turn", European Integration, 29, 1.

Chambre des Députés (2006), « La stratégie européenne de la Chambre des Députés », www.chd.lu.

Clément, F. 2006, « Les Relations professionnelles au Luxembourg », Publications EURES, Differdange.

Collignon, S. 2008, "Why Europe is not becoming the world's most competitive economy? The Lisbon Strategy, macroeconomic stability and the dilemma of governance without Governments", International Journal of Public Policy, 3.

Commission européenne (COM 803 2007), "Strategic report on the renewed Lisbon strategy for growth and jobs: launching the new cycle (2008-2010)".

Conseil économique et social 2008, "Avis dur les lignes directrices intégrées pour la croissance et l'emploi (2008-2010)».

Fontagné, L. 2005, “ Compétitivité du Luxembourg : Une paille dans l'acier. Perspectives de Politique économique ", Ministère de l'Economie et du Commerce extérieur, Luxembourg. 
Hirsch, M. 2003, « Le " modèle luxembourgeois » et ses limites », in Allegrezza, S., Hirsch, M. et Von Kunitzki, N. (Eds.) L'histoire, le présent et l'avenir du modèle luxembourgeois, Institut d'Etudes européennes et internationaux du Luxembourg, Luxembourg, pp. 139-160.

Juncker, J, 2005, in « La Présidence luxembourgeoise du Conseil de l'Union européenne », Service Information et presse du gouvernement luxembourgeois, Luxembourg.

Kok, W., 2004, "Facing the Challenge: the Lisbon Strategy for Growth and Employment".

Ministère de l'Economie et du Commerce extérieur (2005/2008), Plan national pour l'innovation et le plein d'emploi, www.odc.lu.

Ministère d'Etat 2006, Avis du Comité de coordination tripartite.

Radlo, M. 2006, “National Reform Programs and their credibility", in Radlo, J.M. et Bates, C. (Eds.) National Reform Programs: Key to successful future of the European Project?, Gdansk Institute for market Economics, Varsovie.

Thill, P. 2009, “Les parlements et la Stratégie européenne de 1'Emploi (SEE. Vers un dialogue coexistant au Luxembourg ?, REPREM Gouvernance et Emploi, Differdange.

Thill, P., Thomas, A., 2009. « Le modèle luxembourgeois face à la crise », REPREM Gouvernance et Emploi, Differdange (upcoming).

Tsakatika, M. 2007, “A parliamentary dimension of EU soft governance", European Integration, 29, 5.
Zahlen, P., 2003. « La création du modèle luxembourgeois après la Deuxième Guerre mondiale. ", dans Allegrezza, S., Hirsch, M., Von Kunitzki N., L'histoire, le présent et l'avenir du modèle luxembourgeois, Luxembourg, Institut d'études européennes et internationales du Luxembourg. 